\title{
Determination of heavy metals in raw and pasteurized liquid milk of Bangladesh to assess the potential health risks
}

\author{
${ }^{1, * H a s a n, ~ G . M . M . A ., ~}{ }^{2}$ Kabir, M.H. and ${ }^{1}$ Miah, M.A.S. \\ ${ }^{1}$ Institute of Food Science and Technology, Bangladesh Council of Scientific and Industrial Research, Dr. \\ Qudrat-I-Khuda Road, Dhanmondi, Dhaka-1205, Bangladesh \\ ${ }^{2}$ Institute of National Analytical Research and Services, Bangladesh Council of Scientific and Industrial \\ Research, Dr. Qudrat-I-Khuda Road, Dhanmondi, Dhaka-1205, Bangladesh
}

\author{
Article history: \\ Received: 20 March 2021 \\ Received in revised form: 24 \\ April 2021 \\ Accepted: 28 June 2021 \\ Available Online: 13 \\ February 2022
}

Keywords:

Heavy metals,

Milk,

Bangladesh,

Health risk,

Carcinogenic and non-

carcinogenic risk

\section{DOI:}

https://doi.org/10.26656/fr.2017.6(1).191

\begin{abstract}
Milk is a balanced diet and the consumption of milk is increasing day by day in Bangladesh. For public health concerns, it becomes essential to detect the amount of heavy metals in milk and their effects on human health. For this purpose, the potential health risks of adults and children due to consumption of Cow raw milk and liquid Pasteurized milk were accessed. In this research, the concentrations of eight heavy metals namely Iron $(\mathrm{Fe})$, Copper $(\mathrm{Cu})$, Manganese $(\mathrm{Mn})$, Zinc $(\mathrm{Zn})$, Lead $(\mathrm{Pb})$, Cadmium $(\mathrm{Cd})$, Chromium (Cr) and Arsenic (As) in 64 samples of raw and liquid Pasteurized cow's milk were accessed. These samples are collected from 64 different administrative areas of Bangladesh. From this study, it was found that $\mathrm{Cu}$ showed the highest concentration and daily intake rate; while $\mathrm{Pb}$ showed the lowest concentration and daily intake among these metals. Except for Cr, the value of estimated daily intake (EDI) of the heavy metals was found to be lower than the permissible value. From the results of EDI, it can be concluded that the minor potential health risks may occur due to the consumption of raw and liquid pasteurized milk samples. From Target Hazard Quotient (THQ) values, it can be said that there is no chance of non-carcinogenic health risks. From the Target Carcinogenic Risk (TCR) values of $\mathrm{As}$ and $\mathrm{Pb}$, it could be suggested that child milk consumers are sensitive to be exposed to carcinogenic health risk.
\end{abstract}

\section{Introduction}

Milk is a vital component of human nutrition and its consumption has risen in recent years (Khan et al., 2014). The vital nutrients of milk including vitamins and minerals, proteins, lactose and essential fatty acids make it considered a complete food (Licata et al., 2004). Though milk and milk products contain heavy metals in very small amounts, they become toxic during manufacturing and packaging due to alteration by different factors (Khan et al., 2014). There are potential bio-accumulative risk factors in milk including aluminium, lead, cadmium, copper, chromium, zinc, and arsenic (Li et al., 2005). Therefore, the risk to human health posed by exposure to food-based heavy metals varies from other types of pollutants in terms of longterm exposure, the inadequacy of decomposition, nondegradability and high accumulation levels along the food chain (Maas et al., 2011). Raw milk contains 38 micro and trace elements which have been reported from different regions around the world (Nwankwoala et al.,
2002; Dobrzañski et al., 2005). Most of these elements have an essential role in human health. They act as enzymatic co-factors that can play vital roles in the human body's different physiological functions, and the lack of these elements in the whole physiological system can lead to problems (Schuhmacher et al., 1991). Also, the deficiencies of these elements contribute substantially to the global burden of disease. When their amounts are present at higher levels, they may expose a detrimental effect on human health (Meshref et al., 2014). On the other hand, toxic elements also expose negative effects at low concentrations while they are ingested over a long time (Celik and Oehlenschlager, 2007; Uluozlu et al., 2009).

In our current study, Iron $(\mathrm{Fe})$, Copper $(\mathrm{Cu})$, Manganese (Mn), Zinc ( $\mathrm{Zn})$, Cadmium (Cd), Lead ( $\mathrm{Pb}$ ), Chromium (Cr) and Arsenic (As) are the selected heavy metals in milk samples. As babies and children are the main consumers of milk and milk products, the main concern of heavy metals is lead and cadmium because 
lead and cadmium are considered as potential carcinogens (Zhuang et al., 2009).

In addition, due to the toxic level of these metals, babies and children are particularly at high risk for neurotoxic and developmental disorders. Arsenic exposure can also cause various acute problems in human health. Heavy metal emission is increasing day by day for industrialization, urbanization and agricultural mechanization, which has a negative effect on the livestock system and the quality of milk. Therefore, our study aimed to estimate the amount of heavy metals in raw and liquid Pasteurized milk samples and to evaluate their carcinogenic and non-carcinogenic health effects due to consumption of this milk. This analysis was performed using various standard methods and the findings were compared to find out their relationship.

\section{Materials and methods}

\subsection{Sample collection and preparation}

In this study, a total of 64 samples of cow's raw milk and 64 samples of liquid Pasteurized milk were collected from 64 administrative areas of Bangladesh. The 64 raw milk and liquid Pasteurized milk samples were collected from the local markets of 64 administrative areas in Bangladesh. By using the standard method, sterile glass bottles were used to collect samples. Samples were collected in sterile glass bottles, and instantly the glass bottles were kept in an icebox to maintain the temperature below $4^{\circ} \mathrm{C}$. The samples were carried to the laboratory as soon as possible and stored at $4^{\circ} \mathrm{C}$ until analysis. The analysis process was started within 24 hours. The samples were maintained in glass bottles to avoid contact with any metal sources. In this research, the amount of selected heavy metals such as Copper $(\mathrm{Cu})$, Cadmium $(\mathrm{Cd})$, Iron $(\mathrm{Fe})$, Manganese $(\mathrm{Mn})$, Zinc $(\mathrm{Zn})$, Chromium $(\mathrm{Cr})$, Lead $(\mathrm{Pb})$ and Arsenic (As) were estimated in milk samples. The research work was conducted at the Milk, Dairy and Fermented Food Products Research Section of the Institute of Food Science and Technology of Bangladesh Council of Scientific and Industrial Research, Bangladesh. This study was conducted from December 2018 to October 2019.

\subsection{Sample digestion}

The elements were extracted from samples by using a microwave digestion system (Berghof, Germany) with $5 \mathrm{~mL}$ of $\mathrm{HNO} 3$ acid (65\% purity Merck, Germany ) and $2 \mathrm{~mL} \mathrm{H}_{2} \mathrm{O}_{2}$ (30\% purity, Merck, Germany) as digestion reagents.

\subsection{Analysis of sample}

Atomic Absorption Spectrophotometer (iCE -3000 series, Thermo-Scientific, USA) was used for the analysis of heavy metal. The standard solution of analytical grade was purchased from Sigma-Aldrich, USA. The spectral lines were 228.67, 357.65, 324.57, 279.43, 217.35, 213.9, 248.30 and $193.7 \mathrm{~nm}$ for $\mathrm{Cd}, \mathrm{Cr}$, $\mathrm{Cu}, \mathrm{Mn}, \mathrm{Pb}, \mathrm{Fe}, \mathrm{Zn}$ and As respectively. Four standard solutions of each metal at $0.01,0.1,1.0,5.0$ parts per million (ppm) were prepared. The minimum detection limit for $\mathrm{Cr}$, Zn was $0.005 \mathrm{mg} / \mathrm{kg}$, Mn and $\mathrm{Pb}$ was 0.002 $\mathrm{mg} / \mathrm{kg}$ and for $\mathrm{Cd}, \mathrm{Fe}$ and $\mathrm{Cu}$ was $0.001 \mathrm{mg} / \mathrm{kg}$. Certified reference materials (CRMs) of this method were purchased from Sigma Aldrich, USA and they are used to check the quality of the samples.

\subsection{Health risks assessment for Bangladeshi peoples}

\subsubsection{Estimated daily intake (EDI)}

The equation was used to calculate the EDI:

$$
\mathrm{EDI}=\frac{D F C \times M C}{B W}
$$

Here, DFc $=$ Daily Food Consumption Rate $\left(\right.$ gday $\left.^{-1}\right)$; For Bangladeshi people, Adults $=27.31$ gday $^{-1}$ and children $=25.53$ gday $^{-1}(\mathrm{BBS}, 2011)$; MC means the metal concentration in milk samples and BW represents the bodyweight of the population; $60 \mathrm{~kg}$ for adult and 27 $\mathrm{kg}$ for children (Shaheen et al., 2016).

\subsubsection{Target hazard quotient (THQ)}

The target hazard quotient (THQ) is calculated to estimate the potential risk of these heavy metals (USEPA, 2000). The equation is:

$$
\text { THQ }=\frac{E D I}{R f D} \times 10^{-3}
$$

Here, EDI represents the estimated daily intake of metals (mg/day), RfDs indicates reference dose; the reference doses for $\mathrm{Fe}, \mathrm{Cu}, \mathrm{Mn}, \mathrm{Zn}, \mathrm{Pb}, \mathrm{Cd}, \mathrm{Cr}$ and $\mathrm{As}$ are $0.7,0.04,0.05,0.3,0.004,0.001,1.5$ and $0.0003 \mathrm{mg} /$ $\mathrm{kg} \mathrm{BW}^{-1}$ day $^{-1} 9$ (USEPA , 2010). If the value of THQs is equal to or higher than 1 , indicates the potential health risk for this heavy metal (Islam et al., 2011). When consumers are exposed to two or more pollutants, they may suffer from adverse or interactive effects (Hallenbeck, 1993). The total THQ (TTHQ) of these heavy metals is the mathematical sum of the THQ values of each individual metal. TTHQ values can be estimated by the following equation:

$$
\begin{aligned}
& \text { TTHQ }=\text { THQ toxic element } 1+\text { THQ toxic element } 2 \\
& +\ldots+\text { THQ } \text { toxic element } n^{2}
\end{aligned}
$$

\subsubsection{Target carcinogenic risk (TCR)}

When the carcinogens are to be exposed over a lifetime, the probability of cancer of an individual can be developed (USEPA, 1989). The acceptable risk level 
ranges from $10^{-4}$ to $10^{-6}$ for carcinogens. The equation is:

$$
T C R=\frac{E F r \times E D \times E D I \times C S F^{\circ}}{B W \times A T} \times 10^{-3}
$$

Where, EFr means the frequency of exposure (365 days/year), ED express duration of exposure (for adults 70 years and for children 14 years) which is the average human lifetime. BW is the average body weight (where adults $60 \mathrm{~kg}$; children $27 \mathrm{~kg}$ ), AT is the average time for carcinogens, for adults $=(365$ days $/$ year $\times 70$ years $)$ and for children $=(365$ days/year $\times 14$ years $)$ and $\mathrm{CSF}^{\circ}$ means the oral carcinogenic slope factor (USEPA, 2010) which is $1.5 \mathrm{mg} / \mathrm{kg} / \mathrm{day}$ and $0.0085 \mathrm{mg} / \mathrm{kg} /$ day for Arsenic and lead respectively. TCR for $\mathrm{As}$ and $\mathrm{Pb}$ was calculated because they are carcinogenic.

\section{Results and discussion}

In this analysis, the concentrations of Copper $(\mathrm{Cu})$, Iron $(\mathrm{Fe})$, Manganese $(\mathrm{Mn})$, Zinc $(\mathrm{Zn})$, Lead $(\mathrm{Pb})$, Cadmium (Cd), Chromium (Cr) and Arsenic (As) were calculated in 64 samples of cow's raw (non-brand) milk and 64 samples of cow's liquid brand milk specifically for adults and children. The concentrations of metals are presented in Tables 1 and 2 respectively. The mean value of micro-minerals and toxic metals had shown in the descending order of $\mathrm{Cu}>\mathrm{Fe}>\mathrm{Zn}>\mathrm{Mn}$ and $\mathrm{Cr}>\mathrm{As}>\mathrm{Cd}>\mathrm{Pb}$ respectively for both raw milk and liquid Pasteurized milk samples. Among raw milk (non-brand) and liquid Pasteurized milk samples, $\mathrm{Cu}$ had shown the highest concentration, including $0.742 \pm 0.377$ for raw milk samples; whereas $0.807 \pm 0.522$ for liquid Pasteurized milk samples. On the other hand, $\mathrm{Pb}$ had shown the lowest concentration like $0.013 \pm 0.004$ for both raw milk and liquid Pasteurized milk samples. The daily intake of selected eight heavy metals from milk consumption was calculated for the purposes of health risk assessment. The EDIs for adults and children through the consumption of raw and liquid Pasteurized milk is shown in Tables 3 and 4. EDI was calculated for two population groups, specifically adults and children through two types of milk consumption, namely raw milk (nonPasteurized) and liquid Pasteurized milk. The daily intake of $\mathrm{Cu}$ was shown to have the highest value $(\mathrm{mg} /$ day) including $0.3377 \mathrm{mg} /$ day for adults and $0.7016 \mathrm{mg} /$ day for children, through raw milk consumption. Through the consumption of Pasteurized milk, the daily intake of $\mathrm{Cu}$ was also shown to have the highest value (mg/day) like $0.3673 \mathrm{mg} /$ day for adults and $0.7630 \mathrm{mg} /$ day for children. On the other hand, the daily intake of $\mathrm{Pb}$ was shown to have the lowest value (mg/day) like $0.0059 \mathrm{mg} /$ day for adults and $0.0123 \mathrm{mg} /$ day for children for both raw and pasteurized milk samples. The permissible value of these selected heavy metals is presented by Malhat et al. (2012). From the findings, it can be observed that only the daily intake of $\mathrm{Cr}$ of both adults and children exceeds their permissible limit from the consumption of both raw milk and liquid Pasteurized milk. On the other hand, the value of the daily intake of remaining heavy metals is below their permissible limit. On the basis of these results, it can be concluded that $\mathrm{Cr}$ is the component that makes a minor contribution to the potential health risk through the intake of raw and liquid brand milk samples. The value of the daily intake of these heavy metals through the consumption of raw and Pasteurized milk samples may be stated below that the value found in the article of (Muhib et al. 2016).

\subsection{Non-carcinogenic health risk}

The target hazard quotient (THQ) was estimated to know the non-carcinogenic health risks. In this study, the estimated THQs of children and adults from raw milk consumption are presented in Table 5 and the estimated THQs of children and adults from liquid Pasteurized milk consumption are presented in Table 6. From the results, the estimated THQ value of all the metals is below the threshold value of 1 through the consumption of both raw and liquid Pasteurized milk for both adults and children. It can be said that there are no possible non -carcinogenic health risks associated with these metals. The findings are agreed with Islam et al. (2015) and Muhib et al. (2016). TTHQ was accessed in order to know the total potential risk of non-carcinogenic effects caused by more than one factor. In this study, the TTHQs value for adults and children from raw milk consumption are 0.03431 and 0.22157 respectively; also for adults and children from brand milk consumption are 0.08992 and

Table 1. The concentration of heavy metals in raw milk (64 samples) results in ppm (mg/kg)

\begin{tabular}{ccccccccc}
\hline & $\mathrm{Fe}$ & $\mathrm{Cu}$ & $\mathrm{Mn}$ & $\mathrm{Zn}$ & $\mathrm{Pb}$ & $\mathrm{Cd}$ & $\mathrm{Cr}$ & $\mathrm{As}$ \\
\hline Max. & 0.785 & 2.268 & 0.298 & 0.204 & 0.02 & 0.045 & 0.942 & 0.091 \\
Min. & 0.346 & 0.128 & 0.033 & 0.114 & 0.005 & 0.021 & 0.116 & 0.005 \\
Mean & 0.520 & 0.742 & 0.112 & 0.151 & 0.013 & 0.032 & 0.548 & 0.053 \\
SD & 0.115 & 0.377 & 0.064 & 0.021 & 0.004 & 0.005 & 0.229 & 0.029 \\
\hline
\end{tabular}

Table 2. The concentration of heavy metals in pasteurized milk (64 samples) results in ppm (mg/kg)

\begin{tabular}{ccccccccc}
\hline & $\mathrm{Fe}$ & $\mathrm{Cu}$ & $\mathrm{Mn}$ & $\mathrm{Zn}$ & $\mathrm{Pb}$ & $\mathrm{Cd}$ & $\mathrm{Cr}$ & $\mathrm{As}$ \\
\hline Max. & 0.711 & 2.781 & 0.235 & 0.201 & 0.02 & 0.041 & 0.834 & 0.089 \\
Min. & 0.315 & 0.132 & 0.031 & 0.105 & 0.007 & 0.018 & 0.108 & 0.005 \\
Mean & 0.512 & 0.807 & 0.102 & 0.148 & 0.013 & 0.027 & 0.457 & 0.043 \\
SD & 0.109 & 0.522 & 0.050 & 0.024 & 0.004 & 0.006 & 0.225 & 0.026 \\
\hline
\end{tabular}


Table 3. Estimated daily intake of heavy metals (mg/day) from raw milk (non-pasteurized) consumption by the population of Bangladesh

\begin{tabular}{ccccccccc}
\hline Individuals & $\mathrm{Fe}$ & $\mathrm{Cu}$ & $\mathrm{Mn}$ & $\mathrm{Zn}$ & $\mathrm{Pb}$ & $\mathrm{Cd}$ & $\mathrm{Cr}$ & $\mathrm{As}$ \\
\hline Adult & 0.2367 & 0.3377 & 0.0509 & 0.0687 & 0.0059 & 0.0146 & 0.2494 & 0.0241 \\
Child & 0.4917 & 0.7016 & 0.1059 & 0.1428 & 0.0123 & 0.0303 & 0.5182 & 0.0501 \\
\hline
\end{tabular}

Table 4. Estimated daily intake of heavy metals (mg/day) from pasteurized milk consumption by the population of Bangladesh

\begin{tabular}{ccccccccc}
\hline Individuals & $\mathrm{Fe}$ & $\mathrm{Cu}$ & $\mathrm{Mn}$ & $\mathrm{Zn}$ & $\mathrm{Pb}$ & $\mathrm{Cd}$ & $\mathrm{Cr}$ & $\mathrm{As}$ \\
\hline Adult & 0.2330 & 0.3673 & 0.0464 & 0.0674 & 0.0059 & 0.0123 & 0.2080 & 0.0196 \\
Child & 0.4841 & 0.7630 & 0.0965 & 0.1399 & 0.0123 & 0.0256 & 0.4321 & 0.0407 \\
\hline
\end{tabular}

Table 5. Target hazard quotient (THQ) value of raw milk samples for non-carcinogenic health risks

\begin{tabular}{ccccccccc}
\hline Individuals & $\mathrm{Fe}$ & $\mathrm{Cu}$ & $\mathrm{Mn}$ & $\mathrm{Zn}$ & $\mathrm{Pb}$ & $\mathrm{Cd}$ & $\mathrm{Cr}$ & $\mathrm{As}$ \\
\hline Adult & 0.00034 & 0.00844 & 0.00102 & 0.00023 & 0.00148 & 0.0146 & 0.00017 & 0.0080 \\
Child & 0.00070 & 0.01754 & 0.00212 & 0.00048 & 0.00308 & 0.0303 & 0.00035 & 0.1670 \\
\hline
\end{tabular}

Table 6. Target hazard quotient (THQ) value of Pasteurized milk samples for non-carcinogenic health risks

\begin{tabular}{ccccccccc}
\hline Individuals & $\mathrm{Fe}$ & $\mathrm{Cu}$ & $\mathrm{Mn}$ & $\mathrm{Zn}$ & $\mathrm{Pb}$ & $\mathrm{Cd}$ & $\mathrm{Cr}$ & $\mathrm{As}$ \\
\hline Adult & 0.00033 & 0.00918 & 0.00093 & 0.00023 & 0.00148 & 0.0123 & 0.00014 & 0.06533 \\
Child & 0.00069 & 0.00918 & 0.00193 & 0.00047 & 0.00308 & 0.0256 & 0.00029 & 0.13567 \\
\hline
\end{tabular}

0.17691 respectively. In fact, a TTHQ $<1$ does not indicate acute health effects of consumers (Islam, Ahmed and Al-Mamun, 2015). The TTHQ values of both raw and pasteurized milk samples were enough less than 1 . Therefore, there is no risk of adverse effects.

\subsection{Carcinogenic health risk}

The TCR values for As exposure was $6.025 \mathrm{E}-07$ and $0.7833 \mathrm{E}-06$ for adults and children respectively, from raw milk consumption. And the values of As for liquid brand milk were $4.9 \mathrm{E}-07$ and $0.2611 \mathrm{E}-06$ for adults and children, respectively; while for both raw and liquid brand milk samples, the TCR values of $\mathrm{Pb}$ was $8.3583 \mathrm{E}-10$ for adults and $0.8722 \mathrm{E}-09$ for children. The risk of cancer above $10^{-4}$ is considered undesirable, the risk of cancer below $10^{-6}$ is generally considered minimal and the risk of cancer between $10^{-4}$ to $10^{-6}$ is generally considered an acceptable range (USEPA, 2000, 2010). It was found that the TCR value of $\mathrm{Pb}$ was within the acceptable range to the negligible range. While the TCR value of As was within the acceptable range to the unacceptable range. This study indicates that children are more vulnerable than adults in Bangladesh to exposure to harmful or non-essential elements by daily food intake.

\section{Conclusion}

Milk is an important food for people of all ages because of its high nutritional value. The emission of heavy metals is increasing day by day because of continuous industrialization. As the consumption of milk is increasing day by day, it is necessary to detect the amount of heavy metals in milk and their effects on human health. This study will help the consumers to assess their potential health risks through the consumption of milk.

\section{Conflict of interest}

The authors declare no conflict of interest.

\section{Acknowledgement}

The study was part of the R\&D work of "Milk, Dairy and Fermented Product Research Section" of the Institute of Food Science and Technology (IFST), BCSIR. The instrument used in this study was supported by the ADP project allocated by the Ministry of Science of Technology, Bangladesh.

\section{References}

BBS. (2011). Report of the household income and expenditure survey 2010. Bangladesh: Bangladesh Bureau of Statistics, Statistics Division, Ministry of Planning.

Celik, U. and Oehlenschlager, J. (2007). High contents of cadmium, lead, zinc and copper in popular fishery products sold in Turkish supermarkets. Food Control, 18(3), 258-261. https://doi.org/10.1016/ j.foodcont.2005.10.004

Dobrzañski, Z., Kolacz, R., Górecka. H., Chojnacka, K. and Bartkowiak, A. (2005). The content of microelements and trace elements in raw milk from cows in the Silesian region. Polish Journal of Environmental Studies, 14(5), 685-689.

Hallenbeck, W.H. (1993). Quantitative risk assessment for environmental and occupational health. Boca Raton: CRC Press. https:// doi.org/10.1201/9781482264494

Islam, M.S., Ahmed, M.K., Al-mamun, M.H. and Masunaga, S. (2011). Trace metals in soil and vegetables and associated health risk assessment. Environmental Monitoring and Assessment, 186(12), 8727-8739. https://doi.org/ 10.1007/s10661-014- 
4040-y

Islam, M.S., Kawser, M.A., Habibullah, M.A.M. and Shigeki, M. (2015). Assessment of trace metals in foodstuffs grown around the vicinity of industries in Bangladesh. Journal of Food Composition and Analysis, 42, 8-15. https://doi.org/10.1016/ j.jfca.2014.12.031

Islam, M.S., Ahmed, M.K. and Al-Mamun, M.H. (2015). Determination of heavy metals in fish and vegetables in Bangladesh and health implications. Human and Ecological Risk Assessment: An International Journal, 21(4), 986-1006. https:// doi.org/10.1080/10807039.2014.950172

Khan, N., Jeong, I.S., Hwang, I.M., Kim, J.S., Choi, S.H., Nho, E.Y. and Kim, K.S. (2014). Analysis of minor and trace elements in milk and yogurts by inductively coupled plasma-mass spectrometry (ICPMS). Food Chemistry, 147, 220-224. https:// doi.org/10.1016/j.foodchem.2013.09.147

Li, Y., McCrory, D.F., Powell, J.M., Saam, H. and Jackson-Smith, D. (2005). A survey of selected heavy metal concentrations in Wisconsin dairy feeds. Journal of Dairy Science, 88(8), 2911-2922. https:// doi.org/10.3168/jds.S0022-0302(05)72972-6

Licata, P., Trombetta, D., Cristani, M., Giofre, F., Martino, D., Calo, M. and Naccari, F. (2004). Levels of "toxic" and "essential" metals in samples of bovine milk from various dairy farms in Calabria, Italy. Environment International, 30(1), 1-6. https:// doi.org/10.1016/S0160-4120(03)00139-9

Maas, S., Lucot, E., Gimbert, F., Crini, N. and Badot, P.M. (2011). Trace metals in raw cows' milk and assessment of transfer to Comté cheese. Food Chemistry, 129(1), 7-12. https://doi.org/10.1016/ j.foodchem.2010.09.034

Malhat, F., Hagag, M., Saber, A. and Fayz, A.E. (2012). Contamination of Cows milk by heavy metal in Egypt. Bulletin of Environmental Contamination and Toxicology, 88(4), 611-613. https://doi.org/10.1007/ s00128-012-0550-x

Meshref, A.M., Moselhy, W.A. and Hassan, N.E. (2014). Heavy metals and trace elements levels in milk and milk products. Journal of Food Measurement and Characterization, 8(4), 381-388. https:// doi.org/10.1007/s11694-014-9203-6

Muhib, M.I., Chowdhury, M.A.Z., Easha, N.J., Rahman, M.M., Shammi, M., Fardous, Z. and Alam, M.K. (2016). Investigation of heavy metal contents in Cow milk samples from area of Dhaka, Bangladesh. International Journal of Food Contamination, 3, 16. https://doi.org/10.1186/s40550-016-0039-1

Nwankwoala, A., Odueyungbo, S., Nyavor, K. and
Egiebor, N. (2002). Levels of 26 elements in infant formula from USA, UK and Nigeria by microwave digestion and ICPOES. Food Chemistry, 77(4), 43947. https://doi.org/10.1016/S0308-8146(01)00378-8

Schuhmacher, M., Borques, A.M., Domingo, L.J. and Carbella, J. (1991). Dietary intake of lead and cadmium from foods in Tarragona Province, Spain. Bulletin of Environmental Contamination and Toxicology, 46(2), 320-328. https://doi.org/10.1007/ BF01691955

Shaheen, N., Ahmed, M.K., Islam, M.S., Habibullah-AlMamun, M., Tuku, A.B., Islam, S. and Rahim, A.T.M. (2016). Health risk assessment of trace elements via dietary intake of "non-piscine protein source foodstuffs (meat, milk and egg) in Bangladesh. Environmental Science and Pollution Research, 23(8), 7794-7806. https://doi.org/10.1007/ s11356-015-6013-2

Uluozlu, O.D., Tuzen, M., Mendil, D. and Soylak, M. (2009). Assessment of trace element contents of chicken products from Turkey. The Journal of Hazardous Materials, 163(2-3), 982-987. https:// doi.org/10.1016/j.jhazmat.2008.07.050

USEPA. (1989). Risk assessment guidance for superfund, Vol. I, human health evaluation manual.EPA/540/1-89/002.Office of Emergency and Remedial Response, U.S. Environmental Protection Agency, Washington, DC.

USEPA. (2000). Risk-based concentration table. Washington, DC: United States Environmental Protection Agency.

USEPA. (2010). Risk Based Concentration Table. Website: http://www.epa.gov/reg3hwmd/risk/human/ index.htm.

Zhuang, P., McBride, M.B., Xia, H., Li, N. and Li, Z. (2009). Health risk from heavy metals via consumption of food crops in the vicinity of Dabaoshan mine, South China. Science of the total environment, 407(5), 1551-1561. https:// doi.org/10.1016/j.scitotenv.2008.10.061 